\title{
HIGH CADMIUM / ZINC RATIO IN CIGARETTE SMOKERS: POTENTIAL IMPLICATIONS AS A BIOMARKER OF RISK OF PROSTATE CANCER.
}

\author{
J. I. ANETOR ${ }^{1}$, F. AJOSE ${ }^{2}$, G. O. ANETOR ${ }^{3}$, A. A. IYANDA ${ }^{1}$, O. O. BABALOLA ${ }^{1}$ AND F. A. \\ A. ADENIYI ${ }^{1}$ \\ 1. Department of Chemical Pathology, College of Medicine, University of Ibadan, Ibadan, Nigeria. E-mail: \\ anetorji@yahoo.com 2. Department of Medicine, College of Medicine, Lagos State University, Ikeja, Nigeria. \\ 3.Department of Human Kinetics and Health Education, Faculty of Education, University of Ibadan, Ibadan, \\ Nigeria.
}

\begin{abstract}
Summary
Tobacco smoke may be one of the most common sources of cadmium $(\mathrm{Cd})$ in the general population, particularly in the rising population of smokers in developing countries. Although a relationship between both cigarette smoking and environmental Cd contamination with prostate cancer exist, the mechanisms are unclear. Most prospective cohort studies found a positive association between current smoking and a fatal cancer of the prostate. We investigated the interaction between zinc and cadmium and the potential risk of prostate cancer in smokers. Serum cadmium level was significantly $(\mathrm{P}<0.001)$ higher in smokers compared with non-smokers, the level in smokers was three-fold that in non-smokers. In contrast zinc was significantly $(\mathrm{P}<0.001)$ reduced in smokers compared with non-smokers. Unlike $\mathrm{Zn}, \mathrm{Cu}$ was significantly $(\mathrm{P}<0.05)$ higher in smokers than in nonsmokers. Iron $(\mathrm{Fe})$ though higher in smokers was not significantly different. Zinc: cadmium ratio was very significantly $(\mathrm{P}<0.001)$ reduced, implying high cadmium: zinc ratio. This ratio was 4.5 -fold the level in nonsmokers. Total protein, albumin and total globulin levels were all significantly $(\mathrm{P}<0.001)$ reduced in smokers compared with non-smokers respectively. Potassium $\left(\mathrm{K}^{+}\right)$was significantly $(\mathrm{P}<0.05)$ higher in smokers than in non-smokers. Magnesium $(\mathrm{Mg})$ was significantly $(\mathrm{p}<0.01)$ reduced in smokers compared to non-smokers. Altered $\mathrm{Zn}$ status culminating in high $\mathrm{Cd}: \mathrm{Zn}$ ratio appears the central factor in smokers; leading to oxidative stress, DNA damage, mutation, impaired DNA repair, $\mathrm{P}^{53}$ expression, angiogenic effect of $\mathrm{Cu}$ and impaired vitamin A metabolism. These converge in the risk of the carcinogenic process, suggesting high $\mathrm{Cd}$ : $\mathrm{Zn}$ ratio as the critical determinant of the risk of prostate cancer in smokers and possibly a biomarker of susceptibility to this environmental disease.
\end{abstract}

Keywords: Cadmium, Carcinogenesis, Cadmium:zinc ratio, Smokers, Prostate cancer, Biomarker, Mutation

\section{Introduction}

Prostate cancer is a major health problem in both the industrialized and developing countries. It is the most frequently diagnosed male cancer and the second most common cause of cancer death among men accounting for $29 \%$ of all new cases of cancer (Jemal et al. 2004; 2007). The etiology of human prostate cancer is complex and poorly understood however there is evidence that dietary factors are involved in the high incidence of prostate cancer in the United States and Western Europe, implicating environmental or food-derived carcinogens in the initiation of prostate carcinogenesis (Grover and Martin, 2002)

Cadmium $(\mathrm{Cd})$ is a substantial constituent of cigarette smoke (Satarug and Moore, 2004) and is regarded as a human carcinogen based largely on evidence from lung cancers from long-term inhalation of cadmium at high exposure levels (Feld, 1992; IARC,1993; Bakshi et al,2008) The relationship with prostate cancer is less clear, cadmium is also an antagonist of zinc. Although the relationship between smoking and cancer of the prostate was not clear (Hickney,2001), most prospective cohort studies found a positive association between current smoking and fatal cancer of the prostate (Hsing et al, 1990; Hiatt et al, 1994; Rodriguez et al, 1997; Giovanucci et al,1999; Plasko et al 2003).

Zinc is an essential nutrient. Although several risk factors have been implicated in the etiology of cancer of the prostate, only age, race and family history are established risk factors. Similarly, though data from previous twin and family studies suggest genetic component for prostate cancer (Parent and Siemiotycki, 2001) this can be modulated by zinc, a significant factor in gene expression (Alvanja et al, 2003) DNA repair mechanisms defend against exogenous insults which can lead to gene rearrangement, translocations, amplifications and deletions which in turn contribute to cancer development (Hsing et al,2000; Hsing 2001; Pioret and Weston, 2002). Zinc plays a vital role in these repair mechanisms through zinc fingers (Berg et al, 1990; Berdanier, 1998). Zinc and cadmium invariably occur together in nature because of their similar chemical properties. It has been suggested that even small repeated low doses of cadmium could accumulate and mimic zinc, leading to the adverse effects of 
cadmium observed on the prostate (Sancar and Tang, 1993).

Though cadmium has been implicated epidemiologically and experimentally in the etiology of prostate cancer, there is dearth of data on the ratio or relationship between zinc and cadmium and its implications for risk of prostate cancer in smokers. To clarify the possible role of alteration of this normal ratio on DNA repair pathways and prostate carcinogenesis we investigated active cigarette smokers and nonsmokers and the levels of other related biochemical factors including micronutrients. In this report we evaluated the individual and combined effects of cadmium - zinc ratio as a possible predictive biomarker of the risk of prostate cancer in cigarette smokers.

\section{Materials and Methods}

The method adopted in this report is largely as previously described in our earlier report (Anetor and Adeniyi, 2001). In brief 55 apparently healthy male active cigarette smokers were selected for the study. Their mean age was $33 \pm 3.0$ (SD; range 2259) years. A smoker in this study was defined as any subject who smoked at least 4 sticks of cigarette per day and smoked consistently for at least 3 years. The smokers in this study have been smoking for a period ranging 3-45 years (mean $16 \pm 2.0$ years). Forty-one (41) non smokers, (non passive smokers), mean age $30.0 \pm 2.0$ ( $\mathrm{SD}$; range 18-57) years served as controls. Both smokers and controls were on similar dietary intake and resident in the same geographical locale.

\section{Blood Collection}

Ten millitres $(10 \mathrm{ml})$ of blood were collected with a minimum of stasis using disposable plastic syringes and pyrogen free needles (Becton Dickinson and Co Rutherford, NJ), dispensed into disposable "SST" brand Vacutainer tubes (BectonDickinson and Co Rutherford NJ). Serum was obtained from these tubes after separation according to standard methods. All serum samples were frozen until time for analysis.

Biochemical Analyses

This again is as earlier described in our previous paper (Anetor and Adeniyi, 2001). In brief cadmium was determined by the modified methods of Ediger and Coleman (1973) and Alfaro (1973), a modification of the method of Piper and Higgins (1967) - using atomic absorption spectrophotometry (AAS). Copper was determined by the modified method of Alfaro (1973). Zinc was determined by the modified methods of Davies et al. (1968) and Alfaro (1973).

All trace metals were determined using model 403 Perkin-Elmer AAS (Perkin, Elmer, and Oak Brook, IL). Clean metal techniques were employed. Magnesium was determined with Data Medical colorimetric Kit (Data Medical Associate (DMA),
Texas). Total proteins and albumin were determined by the method of Doumas (1975). Total globulin was computed from the difference between total proteins and albumin. Calcium was determined by the method of Howell et al(1966). Total cholesterol was determined by the method of Watson et al (1979). Alkaline phosphatase activity was determined by the method of Bessy Lowry and Brock(1946), serum iron was determined by the colorimetric method of Goodwin, Murphy and Guillmute(1966), while the assay of potassium was conducted using the method of Charlton, Fleming and Zipp(1982). Cd: Zn ratio was obtained by dividing the serum cadmium concentration by that of the zinc to express the $\mathrm{Cd}$ burden per patient, in turn reflecting the cellular $\mathrm{Cd}$ toxic stress.

Data Analysis

Data were analyzed using Hewlett Packard computing system, Model Hp-11-c (Hewlet Packard Portable computer division, Corvallis, USA) and SPSS for windows version 10. Pearson's Correlation Coefficient was used to investigate association between $\mathrm{Cd}$ and $\mathrm{Zn}, \mathrm{Cd}$ vs. duration of smoking, $\mathrm{Cd}$ vs. age, $\mathrm{Cu}$ vs. $\mathrm{Zn}$ and $\mathrm{Cd}$ vs. number of sticks smoked. Results were expressed in mean \pm standard error of mean (SEM). The five percent level $(\mathrm{P}<0.05)$ of significance was employed to determine statistical significance.

\section{Results}

The results are presented in Tables $1-4$. Cadmium was significantly higher in smokers compared with non-smokers $(\mathrm{p}<0.001)$, the level in smokers being three (3) fold than in non-smokers. In contrast $\mathrm{Zn}$ level was significantly reduced in smokers compared with non-smokers $(\mathrm{p}<0.001)$. Unlike $\mathrm{Zn}, \mathrm{Cu}$ was significantly higher in smokers than in non-smokers $(\mathrm{p}<0.05)$. The iron $(\mathrm{Fe})$ level in smokers though higher was not significantly different $(p>0.05)$. The zinc: cadmium ratio was significantly reduced $(\mathrm{p}<0.001)$, implying high cadmium: zinc ratio. This ratio was four and a half (4.5) times the level in non-smokers. Total protein, albumin, total globulins and total calcium levels were all significantly reduced in smokers compared with non-smokers $(\mathrm{p}<0.001)$ in all cases. Total cholesterol was lower in smokers but not significantly so $(\mathrm{p}>0.05)$, potassium $\left(\mathrm{k}^{+}\right)$was slightly but significantly higher in smokers than in non-smokers $(\mathrm{p}<0.05)$. Magnesium $\left(\mathrm{Mg}^{2+}\right)$ was also significantly lower in smokers than in nonsmokers $(\mathrm{p}<0.01)$. Correlation studies showed positive significant association between $\mathrm{Zn}$ and number of cigarette sticks smoked $(r=0.272$, $\mathrm{p}<0.05)$ and age versus $\mathrm{Cu}(\mathrm{r}=0.301, \mathrm{p}<0.05)$ age versus duration of smoking were strongly positively correlated $(\mathrm{r}=0.508, \mathrm{p}<0.01)$. Others were not significantly correlated. 
High cadmium: zinc ratio as biomarker of prostate cancer

Table 1: Age of cigarette smokers, numbers of sticks smoked, duration of smoking.

\begin{tabular}{|c|c|c|}
\hline & $\begin{array}{c}\text { Smokers } \\
(n=55)\end{array}$ & $\begin{array}{c}\text { Non-Smokers } \\
(n=41)\end{array}$ \\
\hline Age (Years) & $33.0 \pm 3.0$ & $30.0 \pm 2.0$ \\
\hline $\begin{array}{c}\text { Number of } \\
\text { sticks }\end{array}$ & $>4$ for at least 3 years \\
\hline $\begin{array}{c}\text { Mean duration } \\
\text { of smoking }\end{array}$ & $16.0 \pm 2.0$ & - \\
\hline Sex & $\begin{array}{c}\text { All male } \\
(\mathrm{n}=55)\end{array}$ & $\begin{array}{c}\text { All male } \\
(\mathrm{n}=41)\end{array}$ \\
\hline
\end{tabular}

Table 2: Serum $\mathrm{Cd}, \mathrm{Zn}, \mathrm{Cu}, \mathrm{Mg}, \mathrm{K}^{+}$and Fe levels in cigarette smokers and non-smokers

\begin{tabular}{|l|c|c|c|c|}
\hline & $\begin{array}{c}\text { Smokers } \\
(n=55)\end{array}$ & $\begin{array}{c}\text { Non- } \\
\text { Smokers } \\
(n=41)\end{array}$ & $t$ & $P$ \\
\hline $\mathrm{Cd}$ & $0.015 \pm$ & $0.005 \pm$ & 17.17 & $<$ \\
$(\mathrm{ug} / 100 \mathrm{ml})$ & 0.01 & 0.0 & & 0.001 \\
\hline $\mathrm{Zn}$ & $85 \pm$ & $99 \pm 2.79$ & 3.92 & $<$ \\
$(\mathrm{ug} / 100 \mathrm{ml})$ & 2.22 & & & 0.001 \\
\hline $\mathrm{Cu}$ & $111 \pm$ & $98 \pm 4.93$ & 2.23 & $<$ \\
$(\mathrm{ug} / 100 \mathrm{ml})$ & 2.59 & & & 0.05 \\
\hline $\mathrm{Mg}$ & $0.81 \pm$ & $0.92 \pm$ & 2.82 & $<$ \\
$(\mathrm{mmol} / \mathrm{L})$ & 0.03 & 0.02 & & 0.01 \\
\hline $\mathrm{K}^{+}$ & $4.2 \pm$ & $4.0 \pm$ & 2.0 & $<$ \\
$(\mathrm{mmol} / \mathrm{L})$ & 0.05 & 0.07 & & 0.05 \\
\hline $\mathrm{Fe}(\mathrm{mmol} / \mathrm{l})$ & $139+7.0$ & $122+12.7$ & 1.98 & $>$ \\
$\mathrm{ug} / \mathrm{dl}$ & & & & 0.05 \\
\hline
\end{tabular}

Tables 3: Serum Calcium, total proteins, albumin, total globulins, alkaline phosphatase in cigarette smokers and non-smokers.

\begin{tabular}{|l|l|l|l|l|}
\hline & $\begin{array}{l}\text { Smokers } \\
(n=55)\end{array}$ & $\begin{array}{l}\text { Non- } \\
\text { Smokers } \\
(n=41)\end{array}$ & $t$ & $P$ \\
\hline $\begin{array}{l}\mathrm{Ca} \\
(\mathrm{mmol} / \mathrm{l})\end{array}$ & $\begin{array}{l}2.30 \quad \pm \\
0.025\end{array}$ & $\begin{array}{l}2.4 \quad \pm \\
0.275\end{array}$ & 2.81 & $<0.01$ \\
\hline $\begin{array}{l}\text { Total } \\
\text { cholesterol } \\
\text { (mmol/l) }\end{array}$ & $149 \pm 6.2$ & $\begin{array}{l}161 \quad \pm \\
8.05\end{array}$ & 1.18 & $>0.05$ \\
\hline $\begin{array}{l}\text { Total } \\
\text { Proteins } \\
\text { (g/L) }\end{array}$ & $72 \pm 0.7$ & $78 \pm 0.8$ & 2.82 & $<$ \\
\hline $\begin{array}{l}\text { Albumin } \\
\text { (g/L) }\end{array}$ & $41 \pm 0.5$ & $44 \pm 0.4$ & 3.62 & $<$ \\
\hline $\begin{array}{l}\text { Total } \\
\text { globulin } \\
\text { (g/L) }\end{array}$ & $30 \pm 0.9$ & $3.5 \quad \pm$ & 3.47 & $<$ \\
\hline $\begin{array}{l}\text { ALP } \\
\text { (I.U./L) }\end{array}$ & $25 \pm 0.87$ & $26 \pm 1.5$ & 1.01 & $>0.05$ \\
\hline $\begin{array}{l}\text { Cd:Zn } \\
\text { ratio }\end{array}$ & $123 \pm$ & $553 \quad \pm$ & 6.51 & $<$ \\
\hline
\end{tabular}

\section{Discussion}

Cigarette smoking represents a source of substantial exposure to cadmium over a prolonged period. Each stick of cigarette contains 1-2 ug of cadmium of which about $10 \%$ is absorbed by the lung. The significantly higher cadmium level found in smokers in this report is consistent with earlier reports that blood cadmium levels for smokers may be up to four times as high as those for non smokers (IPCS,1992) and that because of cadmium's extremely long biological half-life, even ex-smokers have higher $\mathrm{Cd}$ levels than non smokers.

Table 4: Pearson's Correlation studies in cigarette smokers

\begin{tabular}{|c|c|c|c|}
\hline$\cdot$ & Age & 0.508 & $<0.01$ \\
\hline $\begin{array}{c}\text { Duration of } \\
\text { smoking }\end{array}$ & $\mathrm{Zn}$ & 0.272 & $<0.05$ \\
\hline $\begin{array}{c}\text { No. of sticks } \\
\text { smoked }\end{array}$ & $\mathrm{Cu}$ & 0.301 & $<0.05$ \\
\hline $\mathrm{Age}$ & $\mathrm{Zn}$ & 0.045 & $>0.05$ \\
\hline $\mathrm{Cd}$ & $\mathrm{Zn}$ & 0.152 & $>0.05$ \\
\hline $\mathrm{Cu}$ & $\begin{array}{c}\text { No of } \\
\text { sticks } \\
\text { smoked }\end{array}$ & 0.062 & $>0.05$ \\
\hline $\mathrm{Cd}$ & & \\
\hline
\end{tabular}

A relationship between cancers of the prostate in humans who smoke is unclear inspite of suggestive results in rats (Goyer et al.2004). Parenteral administration or oral exposure to cadmium can result in proliferative lesions and tumors of the prostate in rats. The prominent toxic effects of cadmium on testicular tissue are well recognized. As far back as 1919, Alsberg and Schwartz had noted that administration of Cd salts to animals caused bluish discoloration of the testes (Alsberg and Schwartz, 1919). This early observation however escaped further investigation for about forty years. In about the mid-1950s Parizek (1957) rediscovered and exhaustively investigated the destructive effect of $\mathrm{Cd}$ on testicular tissue. The sterilizing effect of $\mathrm{Cd}$ is rapid and experimental animals may become permanently sterile in as short duration as $24 \mathrm{hrs}$ post administration (Parizek and Zahor, 1956; Parizek, 1957). The testes thus seem to be extremely sensitive to the toxic effects of $\mathrm{Cd}$; hemorrhagic necrosis of rodent testes can be induced by $\mathrm{Cd}$ concentrations as low as $0.15 \mathrm{ug} / \mathrm{g}$ (Parizek, 1957).

In contrast the ability of $\mathrm{Cd}$ to induce neoplasms in the prostate of rats appears typically dose related at doses below the threshold for significant testicular toxicity (Gunn et al.1968). Thus initiation of prostate cancer appears as an early event in cancer of the male reproductive system. A report by Lemen et al (1975) among other forms of cancer in exposure to $\mathrm{Cd}$ reported 4 cases of prostate cancer against 0.88 expected. The average age of death was 73 years. This earlier report appears to strengthen this and other tenuous association between cadmium exposure and the incidence of carcinoma of the prostate. Prostate cancer is a relatively, slow growing cancer. This probably parallels the relatively long half life of 
cadmium and the time it takes for the critical ratio between $\mathrm{Cd}$ and $\mathrm{Zn}$ to be upturned. This is probably consistent with the observation by Malins et al (2001) that more than $70 \%$ of cases of $\mathrm{Ca}$ prostate are diagnosed over age 65 years, and that this is possibly explained by the accumulation of mutations and decline in DNA repair during aging.

The very significantly decreased $\mathrm{Zn}$ level in smokers appears to confirm the known mutual antagonism between zinc and cadmium. (Cotzias et al1961; Hill et al 1963; Elsenhans et al 1991; Schümann, 1993) One possible explanation for this could be due to the established competition between $\mathrm{Zn}$ and $\mathrm{Cd}$ for binding sites on metallothionein. This suggests the strong possibility therefore, that increase in cadmium level diminishes zinc levels in smokers. It is also possible that this arises because of the competition for common metabolic pathways by $\mathrm{Cd}$ and $\mathrm{Zn}$. This observed depression of zinc has far reaching implications for cellular activities and genomic stability and by extension for the pathogenesis of prostate cancer. Zinc is central to DNA repair pathways, perturbation of which may be involved in prostate cancer etiology. The positive correlation between number of sticks of cigarette smoked may be an attempt by the body to increase $\mathrm{Zn}$ level though insufficient. This appears to allude to the critical role of zinc. Genomic stability and integrity are important in maintaining accurate DNA replication (Hill et al1963; Berwick and Vineis, 2000). Cadmium alters the fidelity of DNA replication (William et al, 2000), DNA disruptions leads to gene rearrangements, translocations, amplifications and deletions which can contribute to cancer development (Hsing et al, 2000; Hsing, 2001; Pioriet and Weston, 2002).

Another mechanism by which $\mathrm{Cd}$ may participate in the prostate carcinogenic process is by oxidative stress and attendant oxidative injury. Cadmium is associated with increased generation of reactive oxygen species (ROS) (Ho et al, 2003). Zinc reverses oxidative damage as a constituent of cytotoxic copper-zinc superoxide dismutase $(\mathrm{Cu}-$ Zn SOD) (Valle and Falchuk, 1993). The decreased $\mathrm{Zn}$ level may be permissive to DNA oxidative damage which can lead to mutation. Mutation is an important phenomenon in cancers of many sites (Clayson, 2001).

The observed reduced zinc level also appears in line with the hypothesis of Levander and Cheng (1980) and Mills (1981) who stated that an overabundance of one trace element can interfere with the level and metabolic utilization of another element present in normal or marginal concentrations. This is very important owing to the fundamental role of zinc in DNA and protein synthesis and metabolism (Prasad, 1993). The role of zinc in the very fundamental biologic process of protein synthesis is so fundamental that Golden and
Golden (1981) have compared it to an essential amino acid. Proteins are required as regulatory factors which in turn regulate cell cycle which when impaired can lead to the carcinogenic process in the prostate; one of the sites with the highest concentration of zinc in the human body(Kerr, 1964). Cancer is essentially a consequence of disordered genome function. Thus zinc induced genomic instability may contribute to prostate carcinogenesis.

Although well recognized that insulin, lowers blood glucose level, in reality, it has a wideranging effects not only on glucose metabolism but also on potassium homeostasis; cell volume, cell growth and differentiation (1999). Interestingly, the multiple effects of insulin are expressed through a single type of insulin receptor; many of the insulin signaling protein are involved in the normal control of cell growth and differentiation. Insulin is $\mathrm{Zn}$ dependent. In carcinogenesis, where there is abnormal cell growth and differentiation, this is often due to production of abnormal proteins by tumor - causing genes, oncogenes. This can arise from alteration in $\mathrm{Zn}$ status.

Apart from insulin being a zinc dependent hormone it plays a significant role in gene expression which may be impaired by the high $\mathrm{Cd}$ : $\mathrm{Zn}$ ratio and reduce bioavailability of zinc.

Zinc is essential for prostate function (Kerr, 1960) and it has been shown that Zinc deficiency results in increased oxidative DNA damage and disruption of the p53 tumour suppressor protein (Ho et al, 2003). Though men with very high intake of supplemental zinc had a significant two-fold increased risk of prostate cancer (Krone et al, 2001 ), this is probably due to contamination of $\mathrm{Zn}$ supplement with Cd (Krone et al, 2001). Cadmium is a very common contaminant of zinc as they occur in the same ore (IPCS, 1992).

The pathogenesis of Cadmium associated prostate carcinogenesis might include aberrant gene expression resulting in stimulation of Prostatic Cell proliferation or blockage of apoptosis and activation of transcription factors such as metallothionein genes and activation of some proto-oncogenes. All at least in part resulting from reduced Zinc which may enhance disordered cell proliferation with damaged DNA (Kerr, 1960; Sandstead, 1976; Salway, 1999; Goyer et al, 2004). Suppression of DNA repair owing to the aberrant zinc: cadmium ratio would be additive to the population of cells with DNA damage. This may further be accentuated by disruption of p53 as a result of zinc deficiency. Cadmium has been shown to replace zinc in the tumor suppressor protein p53 (Meplan et al, 1999), thereby impairing p53's DNA binding activity. This impairment can decrease the ability of cell to respond to DNA damage; impairing repair processes. 
The $\mathrm{p} 53$ protein is a remarkable protein that is involved in diverse cell functions including detection of DNA damage, the regulation of cell cycle progression and the induction of apoptosis. The p53 gene and the protein it encodes has been aptly called the "guardian of the genome (Lane, 1992) in recognition of the critical role it plays in the life and death of cells. The p53 gene encodes a 53-KD nuclear phospho-protein that is active in regulating the transcription of a number of genes relating to cell cycle progression and apoptosis.

Attenuation of apoptosis and accelerated tumor growth correlates with loss of p53, which can occur with replacement of $\mathrm{Zn}$ by cadmium in the tumor suppressor protein, p53; thereby impairing recognition of DNA damage, repair mechanisms and genome stability. This will ultimately favor accumulation of multiple genetic changes characteristic of development of prostate neoplasia. This suggests that loss of p53-mediated apoptosis secondary to altered cadmium: zinc ratio may be a rate limiting step in prostate tissue tumorigenesis.

The p53 gene and its protein play an important role by recognizing DNA damage triggering repair and apoptosis and inducing cell cycle arrest. It maintains genome stability and prevents accumulation of multiple genetic changes characteristics of development of Carcinogenesis.

The reduced total globulin level may indirectly allude to the reduction in this protein among others. Epithelial carcinogenesis is a multistep process in which an accumulation of genetic events within a single cell line leads to a progressively dysplastic cellular architecture, deregulated cell growth and finally carcinoma. Apart from the possible direct involvement of zinc in the accumulated genetic events, Zn may also be indirectly involved in epithelial carcinogenesis through its regulation of Vitamin A metabolism. (Smith et al, 1973)

Vitamin A is a retinoid which binds to nuclear retinoid receptors, the activation of which results in changes that include controlling cell differentiation. Retinoids, including vitamin A have anti-cancer properties which may reflect their ability to induce differentiation (Brietman et al, 1980; Bollag and Holdener, 1992). But the bioavailability and utilization of vitamin A depends on adequate zinc status (Smith et al, 1973), underscoring the pivotal role $\mathrm{Zn}$ plays in cellular processes and the pathologic significance of alteration in its status. Indeed the toxicity of cadmium is so dependent on the disturbance of zinc metabolism, leading to the description of cadmium as an antimetabolite of Zinc (Vigliani, 1969). This seemed to have been hitherto unrecognized in discussion of cigarette smoking and risk of Ca prostate.

Besides, the significantly reduced $\mathrm{Zn}$ per se, the high $\mathrm{Cd}$ : $\mathrm{Zn}$ or low $\mathrm{Zn}$ :Cd ratio in comparison to non-smokers implies that cellular cadmium burden is substantial. This indicates significantly reduced level of $\mathrm{Zn}$ relative to $\mathrm{Cd}$, thus suggestive of the loss or significant inhibition of the overriding protective effect of $\mathrm{Zn}$ on cadmium toxicity (Parizek, 1957) leading to a raised Cd burden in a given cellular unit and in turn the intensity or enhancing its effect on cellular processes. This may at least in part increase the risk of the potential of development of proliferative lesion in the prostate of smokers probably concomitant with the greater genome instability. This appears consistent with the very recent observation of Goyer, Liu and Waalkes (2004) that the pathogenesis of prostatic cancer (carcinogenesis) might include aberrant gene expression resulting in stimulation of cell proliferation or inhibition of apoptosis. Suppression of DNA repair secondary to reduced $\mathrm{Zn}$ would add to the population of cells with damaged DNA. Thus one consequence of the high cadmium:zinc ratio may be the high error rate and lack of efficient DNA repair systems leading to high mutation rate leading to prostate carcinogenesis.

The ratio of zinc to cadmium concentrations has been so important in some other pathologies that whether an industrial worker is susceptible to hypertension and or coronary heart disease is determined by this ratio (Bosquet, 1979). This has however not been extended to cadmium associated prostatic carcinogenesis. Zinc can sometimes be displaced on the zinc fingers by other divalent metals. Iron, for example has been used to displace zinc on the DNA binding protein that also binds estrogen (Yoko and Alcock, 1994). This protein binds to the estrogen response element of the DNA in the promoter regions encoding estrogen responsive gene products. When this occurs in the presence of $\mathrm{H}_{2} \mathrm{O}_{2}$ and ascorbic acid, damage to the proximate DNA, the estrogen response element occurs. It has been suggested in this circumstance of an iron substituted zinc finger that free radicals are more readily generated with consequences of genomic damage (Conte et al, 1996). This suggestion has been offered as an explanation of how excess iron (iron toxicity) could initiate the cellular changes that occur in carcinogenesis. Similarly, in excess cadmium it can also substitute for zinc in zinc fingers. In this substitution the resultant fingers are nonfunctional, impair DNA repair and function.

The alteration in Zn status may be particularly relevant to developing countries. Although the prevalence of $\mathrm{Zn}$ deficiency is uncertain globally (Sandstead, 1991) it appears commoner among populations of developing countries (Gibson, 1994) where smoking is also on the increase (Anetor and Adeniyi,2001) while it is on the decline in the developed world. A deficiency of Zn ranks among the top ten leading causes of death in developing countries (WHO, 2002). This may be accentuated by the poor recognition of the importance of zinc (Sandstead and Alcock, 1997; WHO, 2002). 
The significantly elevated copper level (may arise from the antagonism between $\mathrm{Cu}$ and $\mathrm{Zn}$ ) though previously thought to be a protective response against cadmium toxicity may indeed favor prostate angiogenesis (Brewer, 2000), which favors cancer or tumor growth. The relationship of copper is not causative but associative; cancer cells proliferate in a high copper environment but in low copper environment cancer cells would remain dormant or grow slowly, increasing survival time of patients (Brewer, 2000). Thus the increase in copper level in part probably arising from the abolishing of the competitive inhibition of $\mathrm{Cu}$ absorption by $\mathrm{Zn}$ in the intestine (Evans, 1970; Shank and Vetter, 1974) may be another pathway by which alteration in zinc metabolism contributes to the risk of Ca prostate.

Whatever the mechanism, one biologic implication of these findings is that high cadmiumzinc ratio may be permissive to malignant proliferation of prostate cells and this relationship may serve as a predictive biomarker of the risk of prostate cancer in cigarette smokers. This appears consistent with the suggestion that cadmium increases the risk for prostate cancer by interacting with Zinc (Achanzar et al, 2001). Zinc is a critical micronutrient in multiple intracellular metabolic pathways, and the prostate contains high concentrations of zinc (Golden and Golden, 1981). Several enzymes involved in the replication of DNA and RNA, such as polymerases, require zinc to function optimally (Golden and Golden, 1981; Prasad, 1993). The prostate has the highest concentration of zinc of any organ of the body; probably reflecting the critical role it plays in prostate health.

Cancerous prostate glands have been shown to have lower level of zinc than do non cancerous gland (Schrodt, 1964; Brys et al, 1997). Though it remains unclear whether zinc is associated with prostate cancer, the current study suggests that it may be a prime candidate as a predictive biomarker of the risk of prostate cancer in cigarette smokers. This appears to corroborate the observations which suggested higher risk in smokers with increased exposure to cadmium (Rodriguez, 1997, Grovanucci et al, 1999; Hickney et al, 2001). Increase $\mathrm{Cd}$ has been shown to cause dosedependent proliferative precancerous lesions in a segment of the prostate (Plankson et al, 2003; Bakshi et al, 2008).

Some studies have also shown an increased concentration of cadmium in prostates with cancer compare to normal glands (Lindegaard et al, 1990; Waalkes et al, 1997; Waalkes et al, 1999). This is indirectly consistent with the findings; in this study in that increased plasma $\mathrm{Cd}$ concentration will ultimately increase prostatic tissue concentration and owing to the mutual antagonism between both elements, displace $\mathrm{Zn}$. The induced $\mathrm{Zn}$ deficiency can lead to DNA disorders (Castro, 1992). The altered $\mathrm{Zn}$ status may also alter Calcium status (Emery and O'Dell, 1993). Zinc deficiency results in an impaired calcium uptake probably due to a decreased synthesis of intestinal calbindin.Calcium plays a crucial role in cell signaling, impairment of which might also contribute to the carcinogenic process. The low Mg level may also play a role in this (Rilvin, 1994).

Though at present there is lack of agreement on the role of cadmium on prostate cancer in cigarette smokers, alteration of $\mathrm{Zn}$ status especially a high ratio of $\mathrm{Cd}$ : $\mathrm{Zn}$ may be a critical factor but this has not been previously explored. It may however serve as a simple reliable predictive biomarker of the risk of cancer of the prostate in smokers. This study appears to provide evidence to show that the convergence of: reduced $\mathrm{Zn}$ level, high $\mathrm{Cd}: \mathrm{Zn}$ ratio, increased $\mathrm{Cu}$ level, decreased total globulin may serve as a simple panel of biomarkers of risk of prostate cancer.

This appears reasonably consistent with the conclusion of Kok et al (1988) who examined serum $\mathrm{Cu}$ and $\mathrm{Zn}$ levels and risk of death from Cancer and Cardiovascular disease level may greatly increase genome instability and permissive to prostate epithelial proliferation that may culminate in cancer. The reduced cholesterol level in smokers though not significantly may be instructive, in that they normally carry elevated cholesterol level. It is not clear if this is a trend consistent with onset of neoplasia; low cholesterol, triglycerides, albumin and prealbumin are among indices suggestive of altered metabolic state in neoplastic related events owing to wasting. Wasting may be induced by tumor necrotic factor (TNF), probably a response to initiation of neoplasia or stressful stimuli (Sacher and McPherson, 2000). Thus their combination may constitute a useful panel of biomarker that may be predictive of the risk of cadmium associated carcinoma of the prostate in smokers. If confirmed such easily accessible panel could serve as surrogate end points for the early detection of prostate cancer risk and improve prevention, management and prognosis. The report of Drasch et al (2005) on selenium cadmium ratio in deceased prostate cancer patients may be a corroboration of the critical role of the ratio of cadmium to zinc and in the genomic activities including stability in the prostate. Though these investigators have suggested that the associated physiological alteration of selenium / cadmium ratio could elevate the increased cancer risk in smokers, this may even be truer of zinc as it is more abundant and important in the prostate.

Further studies involving actual cases of smokers who developed prostate cancer is recommended to assess in depth the molecular basis of interaction between $\mathrm{Cd}$ and $\mathrm{Zn}$ and other 
related disturbances which may be crucial to an improved understanding of the basis of prostate cancer in cigarette smokers and development of reliable panel of biomarkers that will be readily available to both the developing and industrialized nations.

\section{References}

Achanzar, W. E. Diwen, B. A. and Liu, J. (2001).Cadmium-Inducedm alignant transformation of human prostate epithelial cells. Cancer Res. 61:455-458.

Alavanja, M. C. Samanic C. and Dosemeci, M. (2003). Use of agricultural pesticides and prostate cancer risk in the Agricultural Health Study Cohort, Am. J. Epidemiol. 157:800-814.

Alfafro, B. (1973). Copper, Iron and Zinc Metabolism in the rat Ph.D Thesis. The University of Lancaster, Lancaster, England pp.85-100.

Alsberg C. L. and Schwartz, E. W. (1919). Pharmacological action of cadmium. $J$. Pharmacol. 13: 504-505.

Anetor J. I., and. Adeniyi, F. A. A. (2001). Cadmium status in Nigerian Cigarette smokers. Afr. J. Biomed. Res. 4:23-26.

Bakshi, M., Zhang, X, Godoy-Tundidor, Cheng, R.Y.S., Sartor, M.A., Medvedovic , M., and Ho S-M (2008). Transcriptome analysis in normal prostate epithelial cells exposed to low-dose cadmium : oncogenic and immunomodulations involving the action of tumor necrosis factor. Environ. Health Perpect. 116:769-776.

Berdanier, C. D. (1998). Micronutrients in gene expression. In: Advanced Nutrition: Micronutrients, Boca Raton pp. 10 - 14.

Berg, J.M. (1990). Zinc fingers and other metal binding domains. J. Biol. Chem. 265:65136516.

Berwick M. and Vineis, P. (2000). Markers of DNA repair and susceptibility to cancer in humans: an epidemiologic review. J. Nat. Cancer Inst. 92:874-879.

Bessy, O.A., Lowry, O.H. and Brock, M. J. (1946). Method for rapid determination of alkaline phosphatase with 5 cubic milliliters of serum. J Biol. Chem. 164: 321-329.

Bollag, W. and Holdener, E. E. (1992). Retinoids in cancer prevention and therapy. Annal. Oncol. 669:7-20.

Bosquet, W. F. (1979).Cardiovascular and renal effects of cadmium In: Mennear,J. H. A. (ed). Cadmium Toxicity, Marcel Dekker Inc. New York, pp. 133-157.

Brewer, G. (2000).Treatment of metastatic cancer with tetrathiomolybdate, an anti- copper antiangiogenic agent. Phase I study. Clin. Can. Res. 6:1-10.

Brietman, T. R. Selloni, S.E. and Collins, S. J. (1980). Induction of differentiation of human promyelocytic leukaemia cell lines (H160) by retinoic acid. PNAS. 77: 2936-40.

Castro, C. E., Kaspin, L. C., Chen, S. S. and Nolker, S. G. (1992). Zinc deficiency increases the frequency of single strand DNA breaks in rat liver. Nutr. Res. 12:721-736.

Charlton, S. C., Flemming R. C. and Zipp, A. (1982). Solid-phase colorimetric determination of potassium. Clin. Chem. 28:1875-1861.

Clayson, D. B. (2000). Toxicological Carcinogenesis. Florida, Lewis Publishers, pp. 113 - 136.

Conte, D. Narindrasorasak, S. and Sarkar, B. (1996). In vivo and in vitro iron replaced zinc finger, generates free radicals and causes DNA damage. J. Biol. Chem. 271: 5125 - 5130.

Cotzias, G. C., Borg, D. C. and Selleck, B. (1961). Specificity of zinc pathway in the rabbit zinc - cadmium exchange. Am. J. Physiol. 201: 63-66.

Davies, T. J., Musa, M. I, and Dormandy, T. L. (1968). Measurement of Plasma Zinc. J. Clin. Path. 21:359-362.

Doumas, B. T. (1975). Standards methods for total serum protein assays - a co-llaborative study. Clin Chem. 21:159-166.

Drasch, G., Schopfer, J., and Schrauzer, G. N. (2005). Selenium/ cadmium ratios in human prostates: indicators of prostate cancer risk of smokers and non smokers and relevance to the cancer protective effect of selenium. Biol. Trace Elem. Res. 103: 103-107.

Ediger R. A., and Coleman, R. L. (1973). Determination of Cadmium in blood by Delves cup technique. Atom Absorp. Newslett. 12:3-6.

Elsenhans, B, Schümann, K. and Forth W. (1991). Toxic metals: interacting with essential metals. In :Rowland, I.D.( ed). Nutrition,Toxicity and Cancer. CRC Press, Boca Raton, An Arbor, Boston, London , pp 223-258.

Schümann, K. (1993). Interaction between iron and lead. In: Metal- Metal Interactions. Elsenhans, B, Forth, W. and Schümann,K. (eds). Bertelsmann Foundation Publishers, Gütersloh, Germany, pp 56-71.

Emery, M. P. and. O’Dell, B. L (1993). Low Zinc status in rats impairs calcium uptake and aggregation of platelets stimulated by fluoride. Proc. Soc. Biol. Med. 203:480-484.

Evans, G. W. Majors, P. F. and Cornatzer, W. E. (1970).Mechanism of Cadmium and zinc antagonism of copper metabolism. Biochem. Biophys. Res. Commun. 40:1142 - 1148.

Feld, R.D. (1992). Cadmium toxicity. Clin. Chem. News, 18:12.

Gibson, R. (1994). Zinc nutrition in developing countries. Nutr. Res. Rev. 7:151-73.

Giovannucci, E. Rimm, E. B. and A. Ascheria, A. (1999). Smoking and risk of total and fatal 
prostate cancer in United States health professionals. Cancer Epidemiol. Biomarkers Prev. 8: 277 -282.

Giovanucci, E., Rimm E. B. and Ascherio, A. (1999). Smoking and risk of Total and fatal prostate cancer in United States Health Professionals, Cancer Epidemiol. Biomarkers Prev. 8:277-282.

Golden, M. H. W. and Golden, B. E. (1981). Trace elements in human nutrition with particular reference to Zinc and vanadium. Brit. Med. Bull. 37:648-653.

Goodwin, J., Murphy, B. and Guillmute, M. (1966). Direct measurement of serum iron and binding capacity. Clin. Chem. 12:58-69.

Goyer, R. A., Liu J. and Waalkes, M. P. (2004). Cadmium and cancer of the prostate and testes. Biometals. 17:555-558.

Grover, P. L. and Martin, F.L. (2002). The initiation of breast and prostate cancer, Carcinogenesis 23: 1095 - 1102.

Gunn, S.A., Gould, T. C. and Anderson, W. A. D. (1968). Mechanisms of zinc, cystene and selenium protection against cadmium induced vascular injury to mouse testes. J. Reprod. Fertil. 15:65-70.

Hiatt, R. A., Armstrong, M. A. and Klatsky, A. I. (1994). Alcohol consumption, smoking, other risk factors and prostate cancer in a large health plan cohort in California (United States). Cancer Causes Control. 5:66-72.

Hickney, K., Doka, A. and Green, A. (2001). Smoking and Prostate Cancer. Epidemiol. Rev. 23:115-125.

Hill, C. H., Matrone, G., Payne, W. L. and Barber, C. W. (1963). In vivo interactions of cadmium with copper, zinc and iron. J. Nutr. 80:227-235.

Ho, E., Courtemanche, C. and Ames, B. N. (2003). Zinc deficiency induces oxidative DNA damage and increases p53 expression in human lung fibroblast. J. Nutr. 133: 2543 - 2548.

Howell, D. S., Pita J. C. and Marquez, J. F. (1966). Ultramicrospectrophotometic determination of calcium in biologic fluids. Anal. Chem., 38:434-8.

Hsing, A. W., Mclaughing L.M. and Schuman, E. (1990). Diet, tobacco use and fatal prostate cancer: results from the Lutheran Brotherhood Cohort study, Cancer Res. 50: 6836 - 6840.

Hsing, A.W. (2001). Hormones and Prostate Cancer: What's next? Epidemol. Rev. 23:42-58.

Hsing, A.W., Tsao L. and Devesa, S. S. (2000). International trends and Patterns of prostate cancer incidence and mortality. Int. J. Cancer. 85:60-67.

IARC (International Agency for Research on Cancer) (1993). Cadmium and Cadmium Compounds. IARC monograph Eval Carcinog Risk Hum 58: 119-238.
IPCS (International Programme on Chemical Safety) (1992). Cadmium, Environmental Health Criteria 134 Geneva: World Health Organization.

Jemal, A., Siegel, R., Ward, E., Murray, T. , Xu, J. and Thun M.J. (2007). Cancer Statistics, 2007. CA Cancer J. Clin. 57: 43-66.

Jemal, A., Tiwan, R.C., Murray, T., Ghefoor, A., Samuels, A. , Ward, E. and Fever, C. (2004). Cancer Statistics. Cancer J. Clin. 54: 8 -29 .

Kerr, W. K., Keresteci, A. G and Mayoni, H. (1964). The distribution of zinc within human prostate. Cancer 13: 5524-5531.

Kok, F. J., Van-Duijn, C. M., Hofman, A., Van Dervoet, F. A., DeWolfe, C. H., Krone, C. A., Wyse, E. and Ely, J. T. A. (2001).Cadmium in Zinc-containing mineral supplements. Int. J. Food Sci. Nutr. 52:379-82.

Lane, D. P. (1992). p53, guardian of genome. Nature.358: 15-16.

Lemen, R. A., Lee, J. S., Wagoner, J. K. and Blyer, H.P. (1975). Cancer mortality among cadmium production workers, Conference on occupational carcinogenesis. New York, March.

Levander, O. A. and Cheng, L. (1980). Micronutrients Interaction: vitamins, minerals and hazardous elements, Ann. NY Acad. Sci. 355: 1-35.

Lichtenstein, P. Holm, N. V. and Verkasalo, P. K. (2000). Environmental and heritable factors in the causation of cancer: analysis of cohorts of twins from Sweden, Denmark and Finland. $N$. Engl. J. Med. 343:78-85.

Linegaard, P. M., Hansen, S. D., Christensen, J. E., Andersen, B. B. and Andersen, O. (1990). The distribution of cadmium within the human prostate. Biol. Trace Elem. Res. 25: 97-104.

Malins, D. C., Johnson, P. M. and Wheeler, T. M. (2001). Age-related radical-induced DNA damage linked to prostate cancer. Cancer Res. 61: 6025-6028.

Meplan, C.,Mann, K. and Hainaut, P. (1999). Cadmium induces conformational modifications of wild-type p53 and suppresses p53 response to DNA damage in Cultured Cells. J. Biol. Chem. 274: 3163 - 3170.

Mills, C. F. (1981). Interactions between elements in tissues: Studies in animal models. Fed. Proc. 40: $2138-2143$.

Nakamura, K., Yasunaga, Y., Ko, D., Yu, L. L., Moui, J.W., Peeh, L. D. M. (2002). Cadmiuminduced neoplasmic transformation of human prostate epithelial cells. Int. J. Oncol. 20: 543547.

NTP (National Toxicology Programme) (2004). Cadmium and Cadmium Compounds. In: $11^{\text {th }}$ Report on carcinogens. Research Triangle Park, NC: National Toxicology Programme, 111-42111-44. 
http://ntp.niehs.nih.gov/ntp/roc/eleventh/profile s/s028camd.pdf
Sandstead, H. H. and Alcock, N. W. (1997). Zinc: an escential and unheralded nutrient J. Lab.
Serum Copper and Zinc and tne risk oI aean from cancer and cardiovascular disease. Am. J. Epidemiol. 128: 352-359.

Parent, M. E., and Siemiatycki, J. (2001). Occupation and prostate cancer. Epidemiol. Rev. 23:138-144.

Parizek, J. (1957). The destructive effect of cadmium ion on testicular tissue and its prevention by zinc. J. Endocrinol. 15:56-63.

Parizek, J. and Zahor, Z. (1956). Effect of cadmium salts on testicular tissue. Nature. B:1036.

Petering, H., Johnson M. A. and Stemner, K. L. (1971). Studies of zinc metabolism in the rat: dose response effects of cadmium. Arch. Environ. Health. 23:91-101.

Pioriet, M. C. and Weston, A. (2002). DNA damage, DNA repair and mutagenesis. In: Bertino, J.R. (eds). Encylopaedia of Cancer. Boston (MA), Academic Press.

Piper H. G. and Higgins, G. (1967). Estimation of trace metals in biological samples by atomic absorption. Proc. Assoc. Clin. Biochem. 7:190195.

Plankson, L. A., Penson, D. F., Vaughan, T. C., and Standford, J. L. (2003). Cigarette smoking and risk of prostate cancer in middle aged men. Cancer Epidemiol. Biomarkers Prev. 12: $604-$ 609.

Plaskon, L. A. D., Panson, F., Vaughan, T. L. and Standard, J. L. (2003). Cigarette smoking and risk of prostate cancer in middle aged men. Cancer Epidemiol. Biomarkers Prev. 12:604609.

Prasad, A. S. (1993). Zinc and gene expression In: Prasad AS, ed. Biochemistry of Zinc. Plenum Press, New York, pp55-76.

Rivlin, R. S. (1994). Magnesium deficiency and alcohol intake: Mechanisms, Clinical Significance and possible relation to cancer development, J. Am. Coll. Nutr. 13: 416-423.

Rodriguez, C., Tatham L. M., Thun, M. J., Calle, E. E., and Heath, C. W. (1997). Smoking and fatal prostate cancer in a large cohort of adult men, Am. J. Epidemiol. 145:466-475.

Sacher, R. A., and McPherson, R. A. (2000). Widman's Clinical Interpretation of Laboratory Tests. $11^{\text {th }}$ ed. F. A. Davis Company, Phladelphia.pp.50-55.

Salway, J. G. (1999). Diabetes 1: Insulin stimulated glycogen synthesis - signal transduction. In: Metabolism at a Glance. Blackwell Science, Oxford, pp 98-99.

Sancar, A. and Tang, M. S. (1993). Nucleotide excision repair. Photo. Chem. Photo. Biol. 57: 905-921. sanastead, H. H. (19/0). EJJects and dose-response relationship of toxic metals. Norberg, G.F. ed. New York Elsevier, p.100.

Sandstead, H. H. (1991). Zinc deficiency: a public health problem. J Dis. Child. 145:835-859.

Satarug, S. and. Moore, M. R. (2004). Adverse health effects of chronic exposure of low-level cadmium in food stuffs and cigarette smoke, Environ. Health Perspect. 112:1099 - 1103.

Schrodt, G. R. Hall, T. and Whitmore, W. R. Jr. (1964). The concentration of zinc in diseased human prostate glands. Cancer. 17: 1555- 1556.

Shank, K. E. and R. J. Veter, R. J. (1974). The effects of copper, mercury and zinc on the uptake and distribution of cadmium [115] in the albino rat. Environ. Lett. 6:13-18.

Smith, J. C., Mc Daniel, E. G. and Fan, F. F. (1973). Zinc: a trace element essential in Vitamin A metabolism Science. 181:954-955.

Valle, B. L. and Falchuk, K. H. (1993). The biochemical basis of zinc physiology. Physiol. Rev. 73: $79-118$.

Vigliani, E. C. (1969). The biopathology of cadmium. Amer. Ind. Hyg. Ass. J. 30:329- - 340

Waalkes, M. P., Anver M., and Diwan, B. A. (1999).Carcinogenic effects of cadmium in the noble $(\mathrm{NBL} / \mathrm{Cr})$ rat: Induction of pituitary, testicular and injection site tumors and intraepithelial proliferative lesions of the dorsolateral prostate. Toxicol. Sci. 52:154-161.

Waalkes, M. P., Rehm, S., and Cogen, T. P. et al. (1997). Role of Cadmium in the etiology of cancer of the prostate. In: Thomas, J.A, Colby H. D. (ed), Endocrine Toxicology, $2^{\text {nd }}$ ed. Washington DC., Taylor and Francis, pp 227243.

Watson, C. E., Chang, C. E. and Zipp, A. (1979). Solid phase strip test for determination of total serum cholesterol, Clin Chem. 25:1091 - 1096.

WHO (World Health Organization). (2002). The World Health Report 2002: Reducing risks, promoting healthy life style. Geneva, Switzerland, WHO.

Williams, P. L., James, R. C. and Roberts, S. M. (2000). Chemical Carcinogenesis. In: Principle of Toxicology: Environmental and Industrial Application. John Wiley and Sons Inc. New York, P. 78.

Wood, R. D., Mitchell, M., Sgouros J. and Lindahl, J. (2001). Human DNA repair genes. Science. 291:1284- 1289.

Yoko, K., Alcock, N. and Sandstead, H. (1994).Iron and zinc nutriture of premenopausal women: associations of diet with serum ferritin and plasma zinc disappearance. J. lab. Clin. Med. 124:852-861. 
